\title{
Efficient mining of protein kinase structural data
}

\author{
Stephen Maginn ${ }^{1 *}$, Andrew Henry ${ }^{1}$, Paul Labute ${ }^{2}$, Johannes Maier ${ }^{2}$, Nels Thorsteinson ${ }^{2}$ \\ From 8th German Conference on Chemoinformatics: 26 CIC-Workshop \\ Goslar, Germany. 11-13 November 2012
}

Here, we introduce an aligned database of protein kinase structures that can be efficiently explored by sequence, structure, or by ATP pocket ligand (type or similarity). We also discuss an automated protocol for kinase identification, classification and superposition that relies on a curated reference set of structures and sequences covering the wide variety of human protein kinases.

\section{Author details}

'Chemical Computing Group, St Johns Innovation Centre, Cambridge CB4

OWS, UK. ${ }^{2}$ Chemical Computing Group, 1010 Sherbrooke Street West,

Montréal, Québec H3A 2R7, Canada.

Published: 22 March 2013

doi:10.1186/1758-2946-5-S1-P16

Cite this article as: Maginn et al:: Efficient mining of protein kinase

structural data. Journal of Cheminformatics 2013 5(Suppl 1):P16.

\footnotetext{
* Correspondence: smaginn@chemcomp.com

'Chemical Computing Group, St Johns Innovation Centre, Cambridge CB4 OWS, UK
}

Full list of author information is available at the end of the article

Publish with ChemistryCentral and every scientist can read your work free of charge

"Open access provides opportunities to our colleagues in other parts of the globe, by allowing anyone to view the content free of charge."

W. Jeffery Hurst, The Hershey Company.

- available free of charge to the entire scientific community

- peer reviewed and published immediately upon acceptance

- cited in PubMed and archived on PubMed Central

- yours - you keep the copyright

Submit your manuscript here:

http://www.chemistrycentral.com/manuscript/

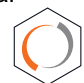

Chemistry Central 